DOI: $10.25178 /$ nit.2017.4.10

\section{ИМЯ СУБУДАЯ В ИМЯНАРЕЧЕНИИ ТУВИНЦЕВ 1980-2000-х ГОДОВ}

\section{THE GIVEN NAME SUBUDAI AMONG THE TUVANS, 1980s-2000s}

\section{Монгуш С. Байыр-оол}

Тувинский институт гуманитарных и прикладных социальноэкономических исследований, Российская Федерация

\author{
Mongush S. Bayyr-ool \\ Tuvan Institute for the Humanities and \\ Applied Social and Economic Studies, \\ Russian Federation
}

В постсоветское время образы Чингис-хана и его соратников стали популярны в центральноазиатских регионах. Для Тувы особо значимым стало имя Субудея (1176-1248), одного из военачальников Чингис-хана, урянхайца по происхождению, которого считают предком современных тувинцев. Статья посвящена анализу распространения имени Субедея в имянаречении тувинцев последних тридцати лет. Источниками выступили данные территориальных органов ЗАГСа по Республике Тыва с 1985 г. до 2016 г., а также сведения об учениках школьных и дошкольных образовательных учреждений республики за 2015 2. Министерства образования и науки Тувы.

Начиная с 10 мая 1985 г. имя «Субудай» было присвоено мальчику, родившемуся в г. Кызыле. С той даты и до 31 января 2016 г. органами Управления ЗАГС по районам республики было зарегистрировано 625 записей актов о рождении мальчиков с этим именем. Наибольшее число их зафиксировано в 2007 2., больше всего за все годы Субудаев стало в столице Тувы - Кызыле (172 чел.). Имя традиционно в написании и произношении имеет варианты. Наиболее

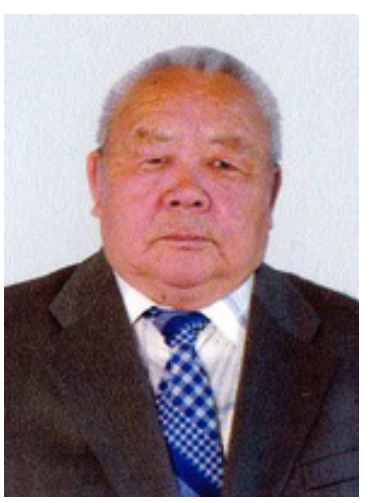

In the post-Soviet period, Genghis Khan and his companions-in-arms have become household names in Central Asis. For Tuva, of special importance is that of Subudei (1176-1248), one of Genghis Khan's chieftains, an Uriankhai by birth and a suggested ancestor of many contemporary Tuvans. This article deals with how often Subudei appears in Tuvan naming practices of the last 30 years. Statistically, the article depends on the data from territorial offices of the ZAGS (Russian registry office) in the Republic of Tuva in 1985-2016, as well as reports of regional Ministry of Education and Science on the status of students at schools and pre-school institutions in 2015.

On May 10, 1985 a boy born in the city of Kyzyl was named Subudai. From that day to January 31, 2016, the ZAGS offices in the raions of Tuva registered 625 cases of boys given that name. The peak year was 2007, and the highest number of cases was registered in Tuva's capital, the city of Kyzyl (172

Байыр-оол Монгуш Сендажиевич - кандидат философских наук, ведущий научный сотрудник сектора прикладной политологии Тувинского института гуманитарных и прикладных социально-экономических исследований. Адрес: 667000, Россия, г. Кызыл, ул. Кочетова, д. 4. Тел.: +7 (394-22) 2-39-36. Эл. адрес: igi@tigpi.ru

Bayr-ool Mongush Sendajievich, Candidate of Philosophy, Leading researcher, Sector of applied political science, Tuvan Institute of Humanitarian and Applied Social and Economic Studies. Postal address: 4 Kochetov St., 667000, Kyzyl, Russian Federation. Tel.: +7 (394-22) 2-39-36. E-mail: igi@tigpi.ru 
распространенные: Субудей (117 детей с 1992 2.), Субудэй (5 детей с 1992 г.). С учетом трех вариантов имени в итоге в Туве насчитывается 747 человек, названных в честь урянхайского полководиа, в возрасте от 1 года до 32 лет. По данным Министерства образования и науки Республики Тыва на 2015 г. насчитывается 242 дошкольников и школьников - тезок урянхайца. Встречаются и женские варианты имени, например, Сувуда.

Традиции имянаречения у тувинцев за XX век претерпели значительные изменения и последние тенденции говорят о желании родителей для детей славной судьбы, лучшей доли, великого пути. И в этом деле имя «Субудай», конечно же, отвечает всем указанным пожеланиям. Распространенность имянаречения Субудаем рождающихся в последние годы мальчиков (и даже, как оказалось, девочек) показывает нам большие надежды населения и значительные жизненные цели, которые могут достигать новые поколения Тувы.

Ключевые слова: Субудай; Субудей; Субудэй; Чингис-хан; тувинцы; урянхайцы; имянаречение; Тува; постсоветское время boys). Traditionally, there has been a good deal of variation in the name's spelling, with the most popular other variants being "Subudei" (117 cases since 1992) and "Subuday" (5 cases since 1992). All the three versions together give 747 cases of people being named for the Uriankhai military leader. At the moment, they are aged 1 to 32. The Ministry for Education and Science reported that as of 2015, 242 namesakes of the Uriankhai study in preschool institutions and schools of the regions. Female versions of the name, such as Suvuda, also exist.

Throughout the 20th century, the Tuvan naming conventions have greatly changed. The most recent trends show that in naming, the parents wish their children a good life, a better lot, and a more glorious path. The name "Subudai" suits all of these wishes well. The wide spread of this name in its male and newly-sprung female versions reveals people's great expectations and lofty goals they set for the new generations of Tuvans.

Keywords: Subudai; Subudei; Genghis Khan; Tuvans; Uriankhai; naming; Tuva; post-Soviet period

\section{Введение}

В постсоветское время образы Чингис-хана и его соратников - средневековых воителей монгольского мира - стали чрезвычайно популярны не только в Монголии, для которой Чингис-хан стал национальным героем, но и в других азиатских регионах, в том числе Туве. Для Тувы особо значимым стало имя Субудея (1176-1248), одного из военачальников Чингис-хана, урянхайца по происхождению. Он покорил Корею, Восточный Туркистан, Персию, Кавказ, разгромил русских (1223 г.), завоевал Китай. Под его командой в великом походе на Запад было 150000 человек. В 1236 году он, уничтожая империю за империей, был уже на Волге, взял Рязанские, Суздальские княжества, сжег Владимир, Москву и Тверь, повернул на юг и разорил дотла Киев (1240 г.).

Как утверждает К. А. Бичелдей, современные тувинцы являются потомками Субудея и его этническая принадлежность не оспаривается Академией наук Монголии (см.: Ховалыг, Шой-Сюрюн, Донгак, 2016: Электр. ресурс). Тувиноведение также включило в поле своих исследований данную историческую личность, даже появился термин «субедееведение» (там же), разработан проект издания научно-популярной книги о Субедей в серии «Жизнь замечательных людей Тувы». 
В современных научных изысканиях имя Субедея стало распространяться не только в исторических работах. Субедей даже стал считаться одним из тех деятелей, которые внесли «немало полезного в организацию секретной службы и тактику агентурной работы», поскольку «выступая в роли агента, использовал различные хитрости и приемы перевоплощения» (Иванов, 2014: 165; см. также: Румянцев, Мальчук, 2016).

В общественной жизни Тувы это имя также стало одним из элементов национальной идеологии, что отразилось на его распространении во всех сфеpax. В 1998 г. состоялась премьера спектакля «Кто ты, Субедей?» в постановке главного режиссера театра, заслуженного артиста России и народного артиста Тувы Алексея Ооржака по пьесе Народного писателя и Заслуженного деятеля искусств Тувы Эдуарда Мижита. Драма-эссе основана на материалах древней монгольской летописи «Сокровенные сказания монголов» и представляет собой размышления о судьбах людей в непростую эпоху завоеваний монголо-татар. Через призму истории Субедея показана проблема сохранения небольшого народа в это сложное время. В 2014 г. в Туве прошел конкурс рисунков «Лучший образ Субудей-Маадыра», организованный инициативной группой и культурным фондом имени Кужугета Шойгу. Организаторы конкурса задались целью утверждения единого образа легендарного ту-

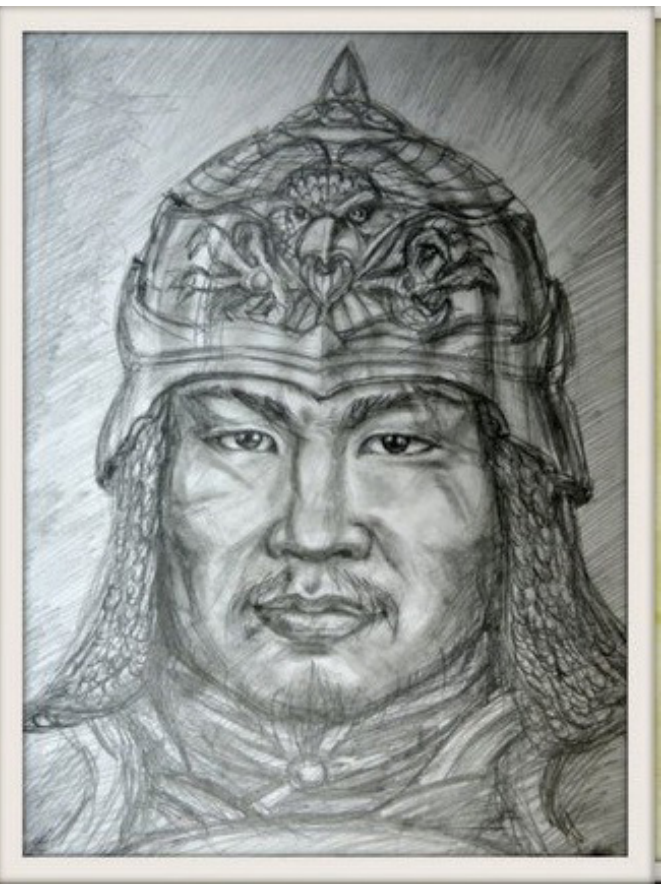

Рис. 1. Рисунок Субудей-Маадыра автора Роберта Балгана - победителя республиканского конкурса 2014 г.

Fig.1. Subudei-Maadyr, a drawing by Robert Balgan, which won the 1st prize in the 2014 regional contest винского полководца Субедея. По итогам народного голосования из 147 работ 108 авторов создателем лучшего художественного образа Субедея был назван художник Роберт Балган (Лучшим образом ..., 2014: Электр. ресурс) (см. рис. 1).

Имя Субедея распространилось в названиях: например, его носит большой спортивный комплекс в г. Кызыле - столицы Тувы. Ученые Тувы рекомендуют еще более развернуть работу по пропаганде жизни и деятельности Субедея среди молодежи в целях воспитания высокого духа и патриотизма, осуществить переводы книг о Субедее и т. д. Периодически возникают разговоры о параллелях в исторической роли между Субудаем и нынешним самым известным тувинцем - министре обороны России С. К. Шойгу.

Настоящая статья посвящена анализу распространения имени Субедея в имянаречении тувинцев, которое покажет нам степень знания в народе этой исторической личности. 


\section{Историческая память}

В советское время считалось, что о Чингис-хане и его соратниках широкая общественность знала мало. Тем не менее пытливым читателям были известны труды ученых Рашид-ад-Дина, Марко Поло (XIII в.), Плано Карпины (XIII в.), Б. Владимирцова, писателей И. Калашникова, В. Яна о знаменитых полководцах. Как отмечают современные исследователи, научные мнения относительно воинов монгольского хана, основанные на распространенной европейской трактовке источников, порой были довольно тенденциозными. Например, В. М. Никифоров пишет о том, что монголов, в том числе Субудай-багатура, называли даже каннибалами, основываясь на буквальном прочтении исторических летописей, наполненных эпическими оборотами (Никифоров, 2007).

Отношение же представителей тюркских и монгольских народов к упомянутым военачальникам, разумеется, было иным. Тувинским читателям особенно интересна и дорога книга калмыцкого ученого Эренжена Хара-Давана (предположительно урянхайского происхождения) «Чингисхан как полководец и его наследие», изданная в Бухаресте в 1926 году (Хара-Даван, 1929; второе издание: Хара-Даван, 1991). В главе «Второй поход на Танчут и смерть Чингисхана» он сообщает, что тело хана привезли на телеге на родину, где оно покоится на горе Бурхан-Халдун. Попытки найти это место успехом не увенчались, но есть упоминания о том, что там же похоронены его сын, любимец отца Тулуй с его детьми. Хранителями этого места автор называет «беков урянхайских племен».

В конце лета и осенью 1929 г. в Туве побывал австрийский ученый Отто Менхен-Хелфен, в то время научный сотрудник Института марксизма-ленинизма в Москве. Он написал книгу «Путешествие в азиатскую Туву», изданную в Германии в 1931 году, в которой есть сведения о нашем герое:

«Моих друзей всегда интересовало, когда я заявлял, что своей поездкой в Туву просто с опозданием отвечаю на нанесенный Субудаем визит в Германию, - написал О. Менхен-Хелфен (Менхен-Хелфен, 2007: 324-325). Дело в том, что, как пишет Менхен-Хелфен, в 1241 г. Субудай собрал около 120000 человек в районе Лемберга (немецкое название г. Львов на Западе Украины). Одна из четырех колонн двинулась на запад по территории Польши, сожгла Краков и захватила Бреславу (старое до 1945 г. название города Вроцлав на юге-западе Польши). 9 апреля 1241 г. под городом Личниц (город в прусской провинции Силезии) пал Герцог Силезии Генрих II. В Моравии армия объединилась с тремя другими колоннами, которые уже успели под предводительством Субудая перейти Карпаты и захватить Венгрию. Монгольские всадники появились у Винер-Нойштадта (город в Австрии) и смогли продвинуться вплоть до итальянских границ - города Удине (город на севере Италии). Только смерть правителя Угедея (Угэдэя) (1186-1241), третьего сына Чингис-хана, и необходимость участия на выборах преемника заставили монголов повернуть назад. Был и второй поход урянхаев в Германию (там же: 325). 
При этом, как писал О. Менхен-Хелфен, за шесть прошедших столетий слава Чингис-хана не потускнела (там же: 325). Это упоминание показывает нам, что историческая память тувинцев многие века хранила имя полководца, в том числе в начале XX века.

В 1982 г. в свет вышел роман-эссе Владимира Чивилихина «Память» о монгольском завоевании средневековой Руси, который был хорошо принят читателями, а также получил высокую награду - Государственную премию СССР 1982 г. Особый живой и восторженный интерес роман вызвал у читателей Тувинской АССР. Автор в произведении, устроив диалог с любознательным читателем, утверждал, что выдающийся полководец XIII века Субедей - личность феноменальная. При этом он перечислил большое количество вариантов имени Субедея в различных монгольских, китайских, латинских и русских источниках: «Субудай, Субсэтай, Субут, Субэдей, Субуэдай, Субсэтай, Субудэй, Субугэдай, Субу-бей, Субетай, Субудэ, Субу, Су-бу-тхай, Субутли, Субеетай, Сибедей, Себедай...» (Чивилихин, 2007: 348).

Под влиянием «Памяти» Владимира Чивилихина в тувинских газетах в 1980-х годах появились статьи, например, «Субедей Маадыр» (Борбай-оол, 1985) и др. Тувинским писателем, драматургом Э. Мижитом была написана пьеса «Кто ты, Субедей?», о которой мы упомянули выше. Помимо этого, в 1990 г. Бурятское книжное издательство выпустило «Сокровенное сказание монголов» в переводе С. А. Козина (Сокровенное сказание ..., 1990).

Стало очевидно, что Субудая потомки никогда не забывали полностью и новый интерес к нему отразился в имянаречении тувинцев.

\section{Субудаи в современной Туве}

Как пишет исследовательница особенностей антропонимии тувинцев $\mathrm{XX}$ века Н. Д. Сувандии, основную часть тувинского именника составляют собственно тувинские имена, образованные от нарицательных слов и, вместе с тем, сохраняющие преемственную связь с последними (Сувандии, 2004: 4). Собственно тувинские имена имеют много общего с антропонимами других тюркских народов, но, как отмечает ученая, конкретные модели образования этих имен во многом специфичны для тувинского языка (там же).

Традиции имянаречения тувинцев обусловили значительное число имен, связанных с минералами, драгоценными камнями; связанные с фауной, с природными явлениями; указывающие на внешность и характер ребенка; отражающие различные обстоятельства рождения; связанные с названиями рода деятельности, с национально-бытовыми особенностями, с числами, топонимами, этнонимами (там же: 7-9). Помимо этого в традиционный период развития тувинского этноса были распространены «охранные» имена - подчеркивающие 
«непривлекательность» детей, или запутывающие пол ребенка для ограждения их от злых духов, забирающих детей (там же: 9).

Распространенность тех или иных имен, например, монгольско-тибетского происхождения, русского или интернационального происхождения была связана с определенными историческими особенностями. Н. Д. Сувандии рассматривает периоды в тенденциях имянаречений, например, русских имен, и для $\mathrm{XX}$ века важнейшими вехами в этом процессе становится общность истории Тувы и России.

Процесс национального возрождения в Туве, как и в других регионах и государствах постсоветского пространства, отразился и на тенденциях имянаречения. В последнее время у тувинцев стала распространенной практика называния детей красивыми, «громкими», значительными именами, связанными с драгоценными металлами, с историческими деятелями, с могучими персонажами фольклора. Снова очевидно возвращение к монгольско-тибетским именам, в том числе благодаря рекомендациям буддийских священнослужителей, к которым нередко обращаются родители за советом.

О том, как распространилось имянаречение у тувинцев именем «Субудай», нам показывают архивные данные, полученные нами в 2016 г. от Управления записи актов гражданского состояния (ЗАГС) по Республике Тыва ${ }^{1}$.

Согласно этим данными, первое имя «Субудай» было присвоено мальчику, родившемуся 10 мая 1985 г. в г. Кызыле. С той даты и до 31 января 2016 г. органами Управления ЗАГС по районам республики было зарегистрировано 625 записей актов о рождении мальчиков с именами «Субудай».

По годам эта статистика выглядит следующим образом:

- 1985 г. - 1 чел. (г. Кызыл);

- 1987 г. - 1 чел. (Эрзинский район);

- 1988 г. - 1 чел. (Тес-Хемский район);

- 1989 г. - 4 чел. (в том числе: Барун-Хемчикский район - 1 чел., БайТайгинский район -1 чел., Дзун-Хемчикский район -2 чел.);

- 1990 г. - 10 чел. (в том числе: г. Кызыл - 4 чел., Бай-Тайгинский район 1 чел., Дзун-Хемчикский район -1 чел., Тандинский район -1 чел., Тоджинский район - чел., Тес-Хемский район - 1 чел., Улуг-Хемский район -1 чел.);

- 1991 г. - 9 чел. (в том числе: Бай-Тайгинский район - 2 чел., Барун-Хемчикский район -1 чел., Дзун-Хемчикский район -2 чел., Кызылский район 1 чел., Пий-Хемский район - 2 чел., Тандинский район -1 чел.);

- 1992 г. - 17 чел. (в том числе: г. Кызыл - 2 чел., Бай-Тайгинский район -

${ }^{1}$ В связи с чем мы выражаем большую признательность начальнику Управления ЗАГС Т. Н. Москаленко. 
2 чел., Барун-Хемчикский район -4 чел., Дзун-Хемчикский район -1 чел., Кызылский район -1 чел., Пий-Хемский район -2 чел., Тандинский район 3 чел., Тес-Хемский - 1 чел., Улуг-Хемский район - 1 чел.);

- 1993 г. - 17 чел. (в том числе: г. Ак-Довурак - 1 чел., Барун-Хемчикский район -4 чел., Каа-Хемский район -1 чел., Кызылский район -1 чел., Овюрский район -2 чел., Тандинский -5 чел., Тес-Хемский район -2 чел.);

- 1994 г. - 22 чел. (в том числе: Бай-Тайгинский район - 2 чел., Барун-Хемчикский район -2 чел., Дзун-Хемчикский район -2 чел., Кызылский район -2 чел., Монгун-Тайгинский район -2 чел., Пий-Хемский район -2 чел., СутХольский район -1 чел., Тандинский район -3 чел., Тес-Хемский район 2 чел., Тоджинский район -1 чел., Улуг-Хемский район -3 чел., Чеди-Хольский район -1 чел.);

- 1995 г. - 24 чел. (в том числе: г. Кызыл -4 чел., г. Ак-Довурак -1 чел., Бай-Тайгинский район -3 чел., Дзун-Хемчикский район -4 чел., Каа-Хемский район -1 чел., Кызылский район -1 чел., Овюрский район -1 чел., ПийХемский район -1 чел., Сут-Хольский район -1 чел., Тандинский район 2 чел., Тоджинский район -2 чел., Улуг-Хемский район -1 чел., Чаа-Хольский район -1 чел., Барун-Хемчикский район -4 чел.);

- 1996 г. - 28 чел. (в том числе: г. Кызыл -8 чел., г. Ак-Довурак -1 чел., Барун-Хемчикский район -4 чел., Дзун-Хемчикский район -4 чел., МонгунТайгинский район -1 чел., Овюрский район -4 чел., Пий-Хемский район 1 чел., Тандинский район -2 чел., Улуг-Хемский район -2 чел., Чеди-Хольский район - 1 чел.);

- 1997 г. - 22 чел. (в том числе: г. Кызыл - 6 чел., г. Ак-Довурак - 1 чел., Дзун-Хемчикский район -2 чел., Каа-Хемский район -1 чел., Кызылский район -2 чел., Монгун-Тайгинский район -2 чел., Пий-Хемский район -1 чел., Тандинский район -1 чел., Тес-Хемский район -3 чел., Тоджинский район 1 чел., Улуг-Хемский район -2 чел., Эрзинский район -1 чел.);

- 1998 г. - 36 чел. (в том числе: г. Кызыл - 7 чел., г. Ак-Довурак - 4 чел., Бай-Тайгинский район -2 чел., Барун-Хемчикский район -3 чел., ДзунХемчикский район - 5 чел., Каа-Хемский район -1 чел., Кызылский район -3 чел., Монгун-Тайгинский район -1 чел., Пий-Хемский район -3 чел., Тандинский район -3 чел., Тес-Хемский район -2 чел., Чаа-Хольский район 1 чел., Чеди-Хольский район -1 чел.);

- 1999 г. - 19 чел. (в том числе: г. Кызыл - 5 чел., г. Ак-Довурак - 2 чел., Бай-Тайгинский район -1 чел., Барун-Хемчикский район -3 чел., Каа-Хемский район -2 чел., Овюрский район -1 чел., Тоджинский район -2 чел., Чеди-Хольский район - 1 чел., Эрзинский район -2 чел.);

- 2000 г. - 32 чел. (в том числе: г. Кызыл - 6 чел., г. Ак-Довурак - 2 чел., Бай-Тайгинский район -3 чел., Барун-Хемчикский район -2 чел., Дзун- 
Хемчикский район -2 чел., Кызылский район -2 чел., Овюрский район 3 чел., Пий-Хемский район -1 чел., Тандинский район -3 чел., Тес-Хемский район -6 чел., Чеди-Хольский район -1 чел., Эрзинский район -1 чел.);

- 2001 г. - 24 чел. (в том числе: г. Кызыл -6 чел., г. Ак-Довурак - 2 чел., Бай-Тайгинский район -3 чел., Барун-Хемчикский район -3 чел., Каа-Хемский район -1 чел., Кызылский район -2 чел., Пий-Хемский район -1 чел., Тандинский район -2 чел., Тоджинский район -2 чел., Чеди-Хольский район -1 чел., Улуг-Хемский район - 1 чел.);

- 2002 г. - 20 чел. (в том числе: г. Кызыл - 5 чел., Бай-Тайгинский район -2 чел., Барун-Хемчикский район -2 чел., Дзун-Хемчикский район -1 чел., Кызылский район - 2 чел., Монгун-Тайгинский район -1 чел., Сут-Хольский район -1 чел., Тес-Хемский район -1 чел., Тоджинский район -1 чел., УлугХемский район - 2 чел., Чаа-Хольский район -1 чел.);

- 2003 г. - 15 чел. (в том числе: г. Кызыл - 4 чел., Бай-Тайгинский район 1 чел., Барун-Хемчикский район -2 чел., Дзун-Хемчикский район -1 чел., Каа-Хемский район - 1 чел., Кызылский район -1 чел., Овюрский район 1 чел., Тандинский район -1 чел., Тес-Хемский район -1 чел., Улуг-Хемский район - 1 чел., Чаа-Хольский район -1 чел.);

- 2004 г. -25 чел. (в том числе: г. Кызыл - 14 чел., Барун-Хемчикский район -2 чел., Дзун-Хемчикский район -3 чел., Каа-Хемский район -1 чел., Кызылский район -1 чел., Монгун-Тайгинский район -1 чел., Тандинский район -2 чел., Улуг-Хемский район - 1 чел.);

- 2005 г. - 26 чел. (в том числе: г. Кызыл - 6 чел., г. Ак-Довурак - 1 чел., Барун-Хемчикский район -3 чел., Дзун-Хемчикский район -6 чел., Каа-Хемский район - 1 чел., Кызылский район - 3 чел., Монгун-Тайгинский район -1 чел., Сут-Хольский район -3 чел., Тоджинский район -1 чел., Улуг-Хемский район -1 чел.);

- 2006 г. - 21 чел. (в том числе: г. Кызыл -6 чел., г. Ак-Довурак -2 чел., Барун-Хемчикский район -1 чел., Дзун-Хемчикский район -3 чел., Каа-Хемский район - 1 чел., Кызылский район -1 чел., Сут-Хольский район -1 чел., Тандинский район -2 чел., Тес-Хемский район -2 чел., Улуг-Хемский район -2 чел.);

- 2007 г. - 41 чел. (г. Кызыл - 16 чел., г. Ак-Довурак - 2 чел., Бай-Тайгинский район -4 чел., Дзун-Хемчикский район -3 чел., Каа-Хемский район -2 чел., Кызылский район -2 чел., Тандинский район -3 чел., Тес-Хемский район 5 чел., Улуг-Хемский район - 2 чел., Чеди-Хольский район -2 чел.);

- 2008 г. -26 чел. (в том числе: г. Кызыл -5 чел., Бай-Тайгинский район 2 чел., Барун-Хемчикский район -2 чел., Дзун-Хемчикский район -2 чел., КааХемский район -1 чел., Кызылский район -2 чел., Овюрский район -2 чел., 
Сут-Хольский район -1 чел.,Тандинский район -2 чел., Тес-Хемский район -2 чел., Улуг-Хемский район -3 чел., Чаа-Хольский район -1 чел., Чеди-Хольский район -1 чел.);

- 2009 г. - 23 чел. (в том числе: г. Кызыл - 4 чел., г. Ак-Довурак -1 чел., Бай-Тайгинский район -3 чел., Барун-Хемчикский район -3 чел., Каа-Хемский район -1 чел., Кызылский район -1 чел., Овюрский район -1 чел., ПийХемский район -1 чел., Тоджинский район -3 чел., Улуг-Хемский район 2 чел., Чаа-Хольский район - 2 чел., Чеди-Хольский район -1 чел.);

- 2010 г. - 22 чел. (в том числе: г. Кызыл - 4 чел., Барун-Хемчикский район -3 чел., Дзун-Хемчикский район - 1 чел., Кызылский район - 3 чел., ПийХемский район -3 чел., Тере-Хольский район -1 чел., Улуг-Хемский район 2 чел., Чаа-Хольский район - 1 чел., Чеди-Хольский район -2 чел., Эрзинский район -2 чел.);

- 2011 г. -25 чел. (в том числе: г. Кызыл -8 чел., Бай-Тайгинский район 1 чел., Барун-Хемчикский район -3 чел., Дзун-Хемчикский район -1 чел., КааХемский район -1 чел., Кызылский район -1 чел., Тандинский район -1 чел., Улуг-Хемский район -5 чел., Чаа-Хольский район -1 чел., Чеди-Хольский район -1 чел.);

- 2012 г. - 29 чел. (в том числе: г. Кызыл - 12 чел., г. Ак-Довурак - 1 чел., Барун-Хемчикский район -2 чел., Дзун-Хемчикский район -4 чел., Каа-Хемский район -3 чел., Овюрский район -1 чел., Сут-Хольский район -1 чел., Тоджинский район -3 чел., Улуг-Хемский район -1 чел., Чаа-Хольский район -1 чел.);

- 2013 г. - 21 чел. (в том числе: г. Кызыл - 12 чел., г. Ак-Довурак - 1 чел., Каа-Хемский район - 1 чел., Кызылский район -2 чел., Тандинский район 1 чел., Тере-Хольский район -1 чел., Улуг-Хемский район -2 чел., Эрзинский район - 1 чел.);

- 2014 г. - 33 чел. (в том числе г. Кызыл - 14 чел., г. Ак-Довурак - 1 чел., Бай-Тайгинский район -3 чел., Барун-Хемчикский район -2 чел., ДзунХемчикский район -1 чел., Каа-Хемский район -1 чел., Кызылский район - 1 чел., Монгун-Тайгинский район -1 чел., Пий-Хемский район -2 чел., Сут-Хольский район -1 чел., Тандинский район -1 чел., Тес-Хемский район -1 чел., Улуг-Хемский район - 1 чел., Чаа-Хольский район - 1 чел., Чеди-Хольский район -1 чел., Эрзинский район -1 чел.);

- 2015 г. - 28 чел. (в том числе: г. Кызыл - 13 чел., г. Ак-Довурак -1 чел., Бай-Тайгинский район -1 чел., Дзун-Хемчикский район -2 чел., Кызылский район -4 чел., Сут-Хольский район -3 чел., Тандинский район -1 чел., ТесХемский район -1 чел., Чаа-Хольский район -1 чел., Эрзинский район 1 чел.). 
Те же данные приведены в диаграмме № 1 .

Из приведенных данных мы видим устойчивый интерес тувинцев к имени «Субедей», которым они называют детей с 1985 года. На диаграмме особенно хорошо заметен всплеск в 2007 году, который можно попытаться объяснить отчасти профессиональным успехом постановки и популярностью спектакля «Кто ты, Субедей?» А. Ооржака по пьесе Э. Мижита.

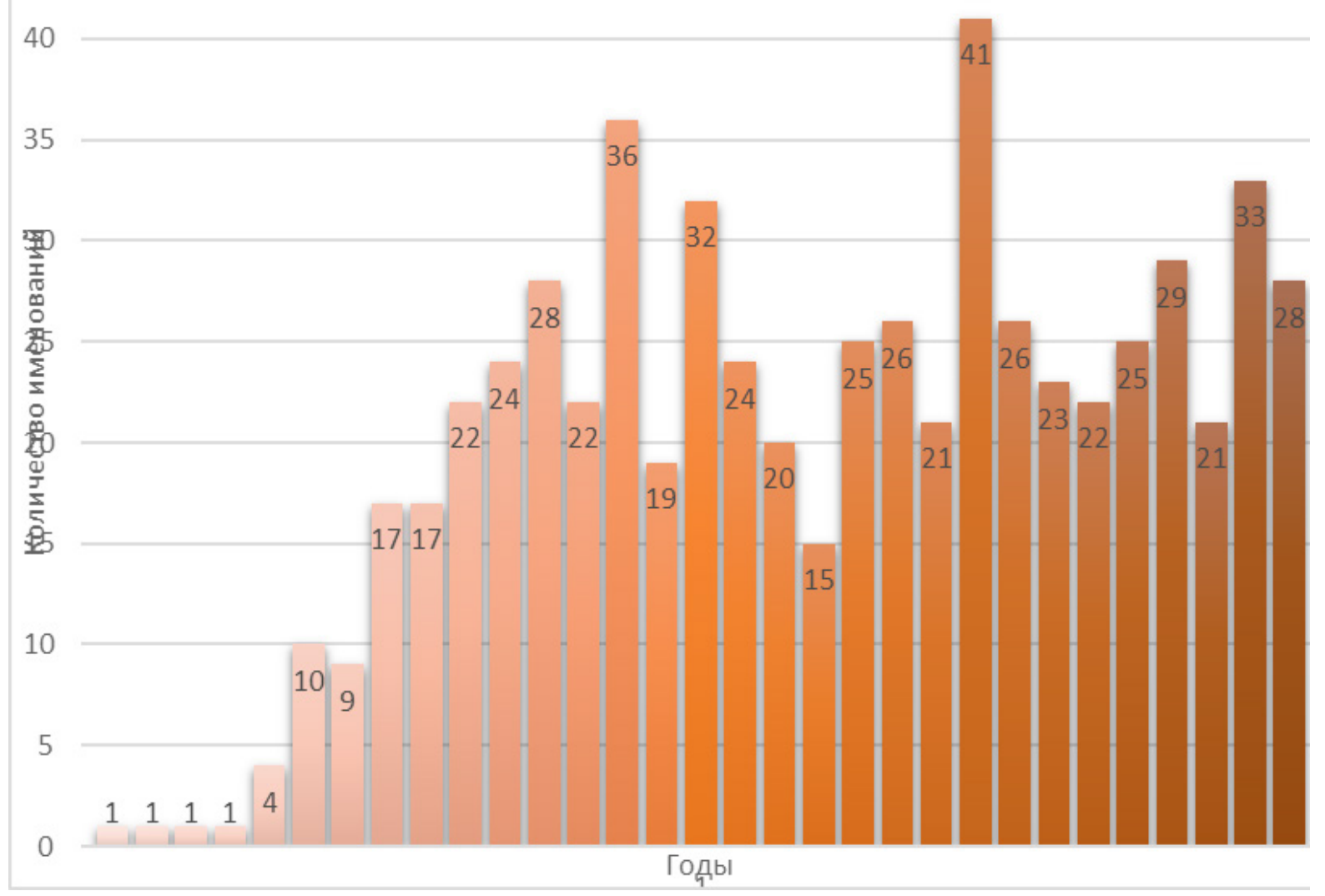

Диаграмма 1. Динамика именований детей именем "Субедей" тувинцами в 1985-2015 г2. Diagram 1. The number of Tuvan children named Subedei in 1985-2015

Также мы отметим из общего количества за указанный период следующий факт: наибольшее количество записей о рождении мальчиков с именами «Субудай» зарегистрировано в органе ЗАГС г. Кызыла - 172 чел. Наименьшее количество зарегистрировано в органе ЗАГС Тере-Хольского района -2 чел. (см. таб. № 1). 
Таблица № 1. Количество мальчиков с именами «Субудай» за период с 10.05.1985 2. по 31.01.2016 2., зарегистрированных по районам Тувы.

Table 1. The number of newborn boys named Subudai from 10.05.1985 to 31.01.2016, by raion of Tuva

\begin{tabular}{|l|c|}
\hline Наименование органа ЗАГС & Количество, чел. \\
\hline г. Кызыл & 172 \\
\hline Дзун-Хемчикский & 53 \\
\hline Барун-Хемчикский & 52 \\
\hline Кызылский & 41 \\
\hline Тандинский & 41 \\
\hline Бай-Тайгинский & 36 \\
\hline Улуг-Хемский & 35 \\
\hline Тес-Хемский & 31 \\
\hline г. Ак-Довурак & 24 \\
\hline Каа-Хемский & 22 \\
\hline Пий-Хемский & 21 \\
\hline Чеди-Хольский & 17 \\
\hline Овюрский & 16 \\
\hline Тоджинский & 16 \\
\hline Сут-Хольский & 14 \\
\hline Чаа-Хольский & 13 \\
\hline Эрзинский & 10 \\
\hline Монгу-Тайгинский & 9 \\
\hline Тере-Хольский & 2 \\
\hline ИТОГО & 625 \\
\hline
\end{tabular}

\section{Субедеи и Субудэи}

Учитывая тот факт, что имя имеет варианты написания и произношения, мы просчитали также и данные по имени «Субудей» и «Субудэй», которые также регистрировались органами ЗАГСа.

Первое имя «Субедей» было присвоено мальчику, родившемуся 30 ноября 1992 г. в Тес-Хемском районе.

За период с 30.11.1992 г. по 31.01.2016 г. территориальными органами Управления ЗАГС зарегистрировано 117 записей актов о рождении мальчиков с именами «Субедей»:

- 1992 г. - 2 чел.;

- 1995 г. -1 чел.;

- 1997 г. - 1 чел.;

- 1998 г. - 2 чел.;

- 1999 г. - 1 чел.;

- 2001 г. - 1 чел.;

- 2002 г. -5 чел.; 
- 2003 г. - 3 чел.;

- 2004 г. - 1 чел.;

- 2006 г. - 4 чел.;

- 2007 г. - 5 чел.;

- 2008 г. - 19 чел.;

- 2009 г. - 12 чел.;

- 2010 г. - 8 чел.;

- 2011 г. - 13 чел.;

- 2012 г. - 12 чел.;

- 2013 г. - 7 чел.;

- 2014 г. - 8 чел.;

- 2015 г. - 9 чел.;

- январь 2016 г. - 3 чел.

Распространенность имени по районам Тувы отражена в таблице № 2.

Таблица № 2. Количество мальчиков с именами «Субедей» за период с 30.11.1992 г. по 31.01.2016 г., зарегистрированных по районам Тувы.

Table 2. The number of newborn boys named Subedei from 30.11.1992 to 31.01.2016, by raion of Tuva

\begin{tabular}{|l|c|}
\hline Наименование органа ЗАГС & Количество, чел. \\
\hline г. Кызыл & 33 \\
\hline Улуг-Хемский & 20 \\
\hline Тес-Хемский & 15 \\
\hline Дзун-Хемчикский & 9 \\
\hline Кызылский & 7 \\
\hline Барун-Хемчикский & 5 \\
\hline Тандинский & 5 \\
\hline г.Ак-Довурак & 4 \\
\hline Монгун-Тайгинский & 3 \\
\hline Тоджинский & 3 \\
\hline Эрзинский & 3 \\
\hline Бай-Тайгинский & 2 \\
\hline Каа-Хемский & 2 \\
\hline Овюрский & 2 \\
\hline Сут-Хольский & 1 \\
\hline Тере-Хольский & 1 \\
\hline Чаа-Хольский & 1 \\
\hline Чеди-Хольский & 1 \\
\hline Пий-Хемский & 0 \\
\hline \multicolumn{1}{|c|}{ ИтОГО } & 117 \\
\hline
\end{tabular}


По данным республиканского органа ЗАГС, первое имя «Субэдэй» было присвоено мальчику, родившемуся 28 июня 1992 г. в г. Кызыле.

За период с 28.06.1992 г. по 31.01.2016 г. территориальными органами Управления ЗАГС зарегистрировано 5 записей актов о рождении мальчиков с именами «Субэдей» - по одному чел. в:

- 1992 г. - г. Кызыл;

- 1996 г. - Эрзинский район;

- 2008 г. - Тес-Хемский район;

- 2014 г. - Монгун-Тайгинскйи район;

- 2016 г. - г. Кызыл.

С учетом трех вариантов имени (Субудай, Субедей, Субудэй) в итоге в Туве насчитывается 747 человек, названных в честь урянхайского полководца, в возрасте от 1 года до 32 лет.

Помимо этого, автор статьи получил данные от Министерства образования и науки Республики Тыва ${ }^{1}$ о количестве в 2015 г. учащихся и детей дошкольных учреждений, названных именем в честь великого полководца. По данным ведомства, в городах и районах Тувы проживают юных Субедеев: город Ак-Довурак - 16 чел., г. Кызыл - 50 чел.; кожууны (районы) Барун-Хемчик 18 чел., Дзун-Хемчик - 26 чел., Кызылский - 29 чел., Бии-Хем (Пий-Хемский) 12 чел., Бай-Тайга -17 чел., Танды - 20 чел., Тес-Хем - 11 чел., Тоджа -2 чел., Сут-Холь - 5 чел., Улуг-Хем - 19 чел., Чаа-Холь - 9 чел., Эрзин -4 чел., Овюр 4 чел. Всего, таким образом в Туве насчитывается 242 дошкольников и школьников - тезок урянхайца.

Интересно отметить, что одна девочка из Самагалтая - Сарыглар Сувуда Андреевна - так названа в честь полководца, но в женском варианте. Абсолютное большинство мальчиков названы именем Субудай, но иногда встречаются и варианты: Сухбат, Суюбай, Субээдай, Субедей, Сумбай, Суйхат, Сухбад.

\section{Заключение}

Российские и зарубежные исследователи, путешественники, посещавшие в конце XIX - начале XX веков Туву, называвшуюся тогда Урянхайским краем, делали выводы о вырождении народа - урянхайцев (тувинцев), считали, что зенит развития его остался в прошлом - во времена Чингис-хана, когда воины-урянхайцы составляли его гвардию, когда жил Субудай (например, см.: Грумм-Гржимайло, 2007: 628). Заключения они свои делали на основе личных наблюдений обнищания основной массы народа, тяжелого экономического

${ }^{1}$ В связи с чем мы благодарим М. В. Монгуш. 
положения региона - колонии Китайской империи. Дальнейший ход истории освобожденного от колониального гнета народа в XX веке показал, что их выводы были поспешными. Тувинцы выжили, увеличились в численности. Они сохранили свой край, свою культуру, свой язык. Также тувинцы сохранили и историческую память о своих славных предках, в том числе Субудае.

Н. Д. Суванди писала о том, что традиции имянаречения у тувинцев за XX век претерпели значительные изменения и последние тенденции говорят о желании родителей пожелания детям славной судьбы, лучшей доли, великого пути. И в этом деле имя «Субудай», конечно же, отвечает всем указанным пожеланиям. Распространенность имянаречения Субудаем рождающихся в последние годы мальчиков (и даже, как оказалось, девочек) показывает нам большие надежды населения и значительные жизненные цели, которые могут достигать новые поколения Тувы.

\section{СПИСОК ЛИТЕРАТУРЫ}

Борбай-оол, М. (1985) Субедей Маадыр // Тываның аныяктары (газета). 14 марта.

Грумм-Гржимайло, Г. Е. (2007) Западная Монголия и Урянхайский край. Т. 3. Антропологический и этнографический очерк этих стран // Урянхай. Тыва дептер : в 7 т. / сост. С. К. Шойгу. М. : Слово. Т. 2. Племена Саяно-Алтая: Урянхайцы (IV век - начало XX в.). 664 с. С. 496-639.

Иванов, С. Н. (2014) Оперативно-розыскная деятельность: историческая ретроспектива // Вестник Удмуртского университета. Серия Экономика и право. № 2-3. C. 161-167.

Лучшим образом Субудей-Маадыра признана работа Роберта Балгана (2014) [Электронный ресурс] // Тува.Азия. 29 декабря. URL: https://www.tuva.asia/news/ tuva/7630-subudey.html (дата обращения: 15.09.2017).

Менхен-Хелфен, О. (2007) Путешествие в азиатскую Туву // Урянхай. Тыва дептер. Антология научной и просветительской мысли о древней тувинской земле и ее насельниках, об Урянхае - Танну-Туве, урянхайцах -тувинцах, о древностях Тувы : в 7 т. / сост. С. К. Шойгу. М. : Слово. Т. 6. Танну-Тувинская народная республика (1921-1944). 584 с. С. 220-351.

Никифоров, В. М. (2007) Известнейших из уранхайцев (фольклорные параллели якутской эпики с монгольским источником XIII века) // Наука и образование. № 1. С. 145-150.

Румянцев, Н. В., Мальчук, О. И. (2016) Развитие оперативно-розыскной деятельности с древних времен до XX века // Вестник Московского государственного лингвистического университета. Серия: Общественные науки. № 3. С. 177-186.

Сокровенное сказание монголов (1990) / перевод Ч. Р. Намжилова, С. А. Козина. Улан-Удэ : Бурятское книжное издательство. 318 с. 
Сувандии, Н. Д. (2004) Тувинская антропонимия : автореф. дисс. ... канд. филол. н. М. 24 с.

Хара-Даван, Э. (1929) Чингисхан как полководец и его наследие. Культурноисторический очерк Монгольской империи XII-XIV века. Белград.

Хара-Даван, Э. (1991) Чингис-хан как полководец и его наследие. Культурноисторический очерк Монгольской империи XII-XIV вв. 2-е изд. / послесловие Л. С. Бурчиновой. Элиста : Калм. кн. изд-во. 321 с.

Ховалыг, Н. К.-К., Шой-Сюрюн, Т. М., Донгак, К. Н. (2016) Круглый стол «Урянхаец Субедей - Великий полководец» (г. Кызыл, 4 декабря 2015 г.) [Электронный ресурс] // Новые исследования Тувы. № 2. URL: https://nit.tuva.asia/nit/ article/view/105 (дата обращения: 15.09.2017).

Чивилихин, В. А. (2007) Память (роман-эссе) // Урянхай. Тыва дептер. Антология научной и просветительской мысли о древней тувинской земле и ее насельниках, об Урянхае - Танну-Туве, урянхайцах -тувинцах, о древностях Тувы : в 7 т. / сост. С. К. Шойгу. М. : Слово. Т. 1. Древние племена Тувы и сопредельных территорий Центральной Азии (II тысячелетие до н. э. - конец XIX в.). 592 с. С. $347-488$.

Дата поступления: 10.10.2017 2.

\section{REFERENCES}

Borbai-ool, M. (1985) Subedei Maadyr. Tyvanyң anyiaktary (newspaper), 14 Mars. (In Tuv.).

Grumm-Grzhimailo, G. E. (2007) Zapadnaia Mongoliia i Uriankhaiskii krai. T. 3. Antropologicheskii i etnograficheskii ocherk etikh stran [Western Mongolia and Uriankhayskii krai. Vol. 3. An anthropological and ethnographic study of these countries]. In: Uriankhai. Tyva depter [Uryankhay. Tyva depter]: in 7 vols. / comp. S. K. Shoigu. Moscow, Slovo. Vol. 2. Plemena Saiano-Altaia: Uriankhaitsy (IV vek - nachalo XX v.) [The tribes of the Sayan-Altai: the Uriyankhai (4th - early 20th century)]. 664 p. Pp. 496-639. (In Russ.).

Ivanov, S. N. (2014) Operativno-rozysknaia deiatel'nost': istoricheskaia retrospektiva [Investigative techniques: a historical retrospective]. Vestnik Udmurtskogo universiteta, Issue Ekonomika i pravo, no. 2-3, pp. 161-167. (In Russ.).

Luchshim obrazom Subudei-Maadyra priznana rabota Roberta Balgana (2014). Tuva.Asia, 29December [online] Available at:https://www.tuva.asia/news/tuva/7630subudey.html (access date: 15.09.2017). (In Russ.).

Menkhen-Khelfen, O. (2007) Puteshestvie v aziatskuiu Tuvu [Travel to Asian Tuva]. In: Uriankhai. In: Uriankhai. Tyva depter [Uryankhay. Tyva depter]: in 7 vols. / comp. S. K. Shoigu. Moscow, Slovo. Vol. 6. Tannu-Tuvinskaia narodnaia respublika (19211944) [Tannu-Tuvan People's Republic (1921-1944)]. 584 p. Pp. 220-351. (In Russ.). 
Nikiforov, V.M. (2007) Izvestneishii iz urankhaitsev (fol'klornye paralleli iakutskoi epiki s mongol'skim istochnikom XIII veka) [The most famous of the Uriankhai (folklore parallels between the Yakut epic and its 13th century Mongolian source)]. Nauka i obrazovanie, no. 1, pp. 145-150. (In Russ.).

Rumiantsev, N. V. and Mal'chuk, O. I. (2016) Razvitie operativno-rozysknoi deiatel'nosti s drevnikh vremen do XX veka [The development of investigative techniques from ancient times to the twentieth century]. Vestnik Moskovskogo gosudarstvennogo lingvisticheskogo universiteta, issue Obshchestvennye nauki, no. 3, pp. 177-186. (In Russ.).

Sokrovennoe skazanie mongolov [Secret history of the Mongols] (1990) / transl. by Ch. R. Namzhilov and S. A. Kozin. Ulan-Ude, Buriatskoe knizhnoe izdatel'stvo. 318 p. (In Russ.).

Suvandii, N. D. (2004) Tuvinskaia antroponimiia [Tuvan anthroponymy]: Thesis of Diss.... Candidate of Philology. Moscow. 24 p. (In Russ.).

Suvandii, N. D. (2009) Tuvinskaia antroponimiia [Tuvan anthroponymy]. Kyzyl, TuvGU. 188 p. (In Russ.).

Khara-Davan, E. (1929) Chingiskhan kak polkovodets i ego nasledie. Kul'turnoistoricheskii ocherk Mongol'skoi imperii XII-XIV veka [Genghis Khan as a military leader and his heritage. A cultural and historical essay of the Mongol Empire in XIIXIV century]. Belgrad. (In Russ.).

Khara-Davan, E. (1991) Chingis-khan kak polkovodets i ego nasledie. Kul'turnoistoricheskii ocherk Mongol'skoi imperii XII-XIVvv. [Genghis Khan as a military leader and his heritage. Cultural-historical essay of the Mongol Empire in XII-XIV century]. 2nd ed. Elista, Kalm. kn. izd-vo. 321 p. (In Russ.).

Khovalyg, N. K.-K., Shoi-Siuriun, T. M. and Dongak, K. N. (2016) Kruglyi stol «Uriankhaets Subedei - Velikii polkovodets» (g. Kyzyl, 4 dekabria 2015 g.) ['Subutai of the Uriankhai, a great military commander': A roundtable (Kyzyl, 4 December 2015)]. The New Research of Tuva, no. 2 [online] Available at: https://nit.tuva.asia/ nit/article/view/105 (access date: 15.09.2017). (In Russ.).

Chivilikhin, V. A. (2007) Pamiat' (roman-esse) [Memory (an essay novel)]. In: Uriankhai. Tyva depter [Uryankhay. Tyva depter]: in 7 vols. / comp. S. K. Shoigu. Moscow, Slovo. Vol. 1. Drevnie plemena Tuvy i sopredel'nykh territorii Tsentral'noi Azii (II tysiacheletie do n. e. - konets XIX v.) [The ancient tribes of Tuva and adjacent territories of Central Asia (from 2nd Millennium BC to the end of 19th century)]. 592 p. Pp. 347-488. (In Russ.). 


\section{Для цзитирования:}

Байыр-оол М. С. Имя Субудая в имянаречении тувинцев 1980-2000-х годов [Электронный ресурс] // Новые исследования Тувы. 2017, № 4. URL: https://nit.tuva. asia/nit/article/view/745 (дата обращения: дд.мм.гг.). DOI: 10.25178/nit.2017.4.10

\section{For citation:}

Bayyr-ool M. S. The given name Subudai among the Tuvans, 1980s-2000s. The New Research of Tuva, 2017, no. 1 [on-line] Available at: https://nit.tuva.asia/nit/article/view/745 (accessed:... ). DOI: 10.25178/nit.2017.4.10 